\title{
PENGARUH LIKUIDITAS, PROFITABILITAS, UKURAN PERUSAHAAN, KOMISARIS INDEPENDEN TERHADAP AGRESIVITAS PAJAK DAN PENGUNGKAPAN CSR SEBAGAI MODERASI
}

\author{
Magdalena Erlina \\ Magister Administrasi Bisnis, Program Pasca Sarjana, Universitas Katolik Parahyangan, Bandung \\ magdalenerlina@gmail.com
}

\begin{abstract}
ABSTRAK
Tujuan dari penelitian ini adalah untuk menganalisis pengaruh likuiditas, profitabilitas, ukuran perusahaan dan komisaris independen terhadap agresivitas pajak yang dimoderasi oleh pengungkapan Corporate Social Responsibility (CSR) pada perusahaan pertambangan di Indonesia yang terdaftar pada Bursa Efek Indonesia (BEI). Penelitian ini merupakan penelitian kuantitatif menggunakan metode deskriptif dan verifikatif. Pengambilan sampel perusahaan menggunakan teknik purposive sampling dan sumber data berasal dari laporan keuangan, laporan tahunan dan laporan tahunan pengungkapan CSR perusahaan pertambangan yang terdaftar di BEI dan dipublikasikan pada periode tahun 2018-2019. Teknik analisis data menggunakan Structural Equation Model (SEM) jenis Partial Least Square (PLS) yang didukung perangkat lunak SmartPls 3.0. Hasil penelitian menunjukkan bahwa secara parsial profitabilitas berpengaruh signifikan terhadap agresivitas pajak sedangkan likuiditas, ukuran perusahaan, komisaris independen dan pengungkapan CSR tidak berpengaruh signifikan terhadap agresivitas pajak. Selain itu pengungkapan CSR sebagai variabel moderasi tidak berpengaruh signifikan untuk memperkuat atau memperlemah hubungan likuiditas, profitabilitas, ukuran perusahaan dan komisaris independen terhadap agresivitas pajak.
\end{abstract}

Kata kunci: Likuiditas, Profitabilitas, Ukuran Perusahaan, Komisaris Independen, Pengungkapan CSR, Agresivitas Pajak

\begin{abstract}
This study aimed to analyze the effect of liquidity, profitability, firm size, independent commisioner toward tax aggressiveness and moderated by corporate social responsibility (CSR) disclosure in Indonesian mining companies listed on Indonesian Stock Exchange (IDX). This research used quantitative approach with descriptive and verification method. A sample of companies using purposive sampling technique and research data comes from financial reports, annual reports and annual reports of CSR disclosure of mining companies listed on the IDX and published in the period 2018-2019. Partial least square (PLS)-Structural Equation Model (SEM) was used as the method of analysis to examine the effect of the above variables supported by SmartPls 3.0 software system. The results shows that partially profitability affect significantly toward tax aggressiveness. However, liquidity, firm size, and independent commissioner have no partial effect on tax aggressiveness. As for the moderating effect, the result also shows that CSR disclosure does not significantly affect to strengthen or weaken the correlation between liquidity, profitability, firm size and independent commissioner toward tax aggressiveness.
\end{abstract}

Keywords: Liquidity, Profitability, Firm Size, Independent Commissioner, CSR Disclosure, Tax Aggressiveness

\section{PENDAHULUAN}

Saat ini perusahaan tidak hanya dihadapkan pada profit oriented, tapi juga berkewajiban untuk memperhatikan dan bertanggung jawab terhadap masyarakat maupun planet atau bumi yang dikenal dengan triple bottom line (Elkington, 2004). Aktivitas sosial yang dilakukan oleh suatu perusahaan, diungkapkan dalam laporan CSR (Corporate Social Responsibility Disclosure) yang merupakan salah satu persyaratan pendirian perusahaan yang ditetapkan oleh pemerintah (Undang-undang RI
No.40 Tahun 2007, 2007). Perusahaan diwajibkan melakukan aktivitas CSR dan melaporkan pengungkapan CSR dalam laporan tahunan perseroan dan dipertanggungjawabkan kepada RUPS (Kemenkumham, 2012). Selain mengutamakan kinerja secara keuangan suatu perusahaan juga didukung dengan penerapan kinerja secara non keuangan. Keseluruhan kinerja yang dilakukan oleh suatu perusahaan dalam rangka untuk mendatangkan keuntungan tak lain sangat berkaitan erat dengan pembayaran pajak yang merupakan kewajiban perusahaan untuk memberikan kontribusi sebagai wajib pajak badan 
atas usaha yang dilakukan dan bertempat kedudukan di Indonesia (Undang-undang RI No 36 Tahun 2008, 2008). Pajak merupakan salah satu sumber penerimaan negara yang yang sangat penting untuk kesejahteraan rakyat dan dalam memajukan suatu negara. Dikaitkan dengan kewajiban perpajakan, setiap perusahaan memiliki strategi yang berbeda-beda untuk melakukan pengendalian pajak dalam rangka meminimalisir resiko pajak. Sebagai negara berkembang, perusahaan di Indonesia cenderung melakukan praktik pajak agresif karena sebagian besar penerimaan negara bergantung dari penerimaan pajak (Mohanadas et al., 2019). Tindakan agresivitas pajak yang dilakukan oleh perusahaan akan dipengaruhi oleh kondisi kinerja perusahaan tersebut, praktik ini dapat berupa tindakan untuk merekayasa penghasilan kena pajak yang dapat berupa penghindaran pajak (tax avoidance) ataupun penggelapan pajak (tax evasion) (Purwanto et al., 2016). Perbedaan dari kedua praktik tersebut adalah sisi legalitasnya, tindakan tersebut merupakan upaya yang dipandang dapat memberikan keuntungan secara ekonomi serta mampu mengefisiensikan biaya yang tentunya akan berpengaruh terhadap ekuitas (Lin et al., 2019). Agresivitas pajak merupakan usaha perusahaan untuk meminimalkan beban pajak yang harus dibayar oleh perusahaan. Semakin besar usaha penghematan pajak yang dilakukan perusahaan, maka semakin agresif terhadap pajak. Dari data tahun 2014 kasus penggelapan pajak yang terjadi di Indonesia sebesar 23,89 triliun rupiah berasal dari sektor pertambangan yang bersumber dari misinvoicing trade (Saputra \& Abdullah, 2015). Misinvoicing trade diduga terjadi karena adanya tambang-tambang ilegal yang beroperasi dan ekspor komoditi pertambangan yang tidak tercatat. Hal ini dapat menyebabkan terjadinya praktek tax evasion dan tax avoidance (Kar \& Spanjers, 2014). Sistem perpajakan self assesment yang ditetapkan di Indonesia memberikan peluang bagi para perusahaan untuk dapat melakukan pengendalian pajaknya masing-masing. Berbagai kasus telah banyak terjadi berkaitan dengan praktik manajemen perpajakan ilegal yang dilakukan oleh korporasi, salah satunya mengenai dugaan kasus pengelapan pajak di tahun 2019 oleh salah satu perusahaan pertambangan di Indonesia yang melibatkan perusahaan afiliasinya di luar negeri menjadi salah satu celah yang dapat dilakukan oleh perusahaan untuk terlibat dalam praktik tindakan pajak agresif yang bertentangan dengan peraturan perpajakan di Indonesia (Sugianto, 2019).

Perusahaan pertambangan merupakan salah satu sektor industri di Indonesia yang terpenting yang memiliki posisi dominan dalam memajukan perekonomian di Indonesia, namun keberadaan perusahaan pertambangan juga tak lepas dari sisi negatif yang berdampak terhadap lingkungan, sosial, dan budaya sehingga untuk meminimalisir dampak negatif tersebut, perusahaan pertambangan memiliki peran aktif dalam menjalankan aktivitas CSR bagi masyarakat sekitar yang pada akhirnya dapat memberikan kontribusi besar bagi pengembangan dan kemajuan suatu daerah (Agincourt Resources, 2019; Dunia Tambang, 2020). Hal ini pun tertuang dalam peraturan mengenai pertambangan untuk melakukan berbagai program pengembangan dan pemberdayaan masyarakat (Undang-undang RI No. 4 tahun 2009, 2009) sehingga merupakan suatu kewajiban bagi perusahaan. Tindakan CSR yang dilakukan oleh perusahaan berpengaruh terhadap tindakan agresivitas pajak yang dilakukan oleh perusahaan, aktivitas CSR yang dilakukan dapat berperan untuk tidak atau meminimalisir agresivitas pajak (Lanis \& Richardson, 2012). Seberapa besar perusahaan mengadopsi praktik agresivitas pajak dipengaruhi oleh kinerja keuangan maupun non keuangan suatu perusahaan. Kinerja keuangan perusahaan yang dinilai dari rasio profitabilitas dan likuiditasnya yang semakin meningkat akan meningkatkan pula kemampuan perusahaan dalam menghasilkan profit (Renfiana \& Dewi, 2020), hal ini akan berpengaruh terhadap beban pajak secara korporasi. Pengelolaan perusahaan dari sisi kinerja non keuangan yang dinilai dari seberapa besar ukuran perusahaan juga berpengaruh bagi perusahaan untuk meningkatkan kekuatan perusahaan dalam negosiasi bisnis antar perusahaan serta memberikan kemudahan untuk mendapatkan berbagai sumber pendanaan yang 
akan meningkatkan nilai perusahaan (Kurnia Saputri \& Giovanni, 2021). Selain itu jumlah komisaris independen dalam suatu perusahaan juga dapat berpengaruh terhadap agresivitas pajak, keberadaan komisaris independen merupakan salah satu penerapan tata kelola perusahaan yang berkaitan erat dengan pengawasan terhadap manajemen dalam pengambilan keputusan manajerial dalam pengelolaan perusahaan yang berorientasi terhadap maksimalisasi laba perusahaan (Alkausar et al., 2020). Penelitian ini bertujuan untuk dapat mengetahui seberapa besar pengaruh dari likuiditas, profitabilitas, ukuran perusahaan dan komisaris independen terhadap agresivitas pajak suatu perusahaan dan seberapa besar peran aktivitas CSR yang diwujudkan dalam bentuk pengungkapan CSR memoderasi hubungan diantara kedua variabel tersebut. Diharapkan aktivitas CSR yang dilakukan oleh perusahaan untuk kepentingan masyarakat dapat menjadi panduan bagi perusahaan lainnya dan tidak semata-mata bertujuan untuk menutupi tindakan agresivitas pajak yang dilakukan oleh perusahaan. Agresivitas pajak yang dilakukan oleh perusahaan menjadi hal yang menarik untuk dianalisa lebih lanjut, dimana perusahaan akan berupaya untuk mengurangi beban pajak sedangkan target penerimaan pajak yang ditetapkan oleh pemerintah semakin meningkat tiap tahunnya. Dengan mengetahui seberapa besar pengaruh dari variabel tersebut terhadap agresivitas pajak yang dilakukan oleh perusahaan ditujukan agar dapat memberikan insight dan pertimbangan bagi perusahaan dalam menentukan strategi dalam perencanaan pajak yang akan dilakukan dengan tetap mematuhi peraturan perpajakan yang berlaku serta dapat mempertimbangkan dampak resiko perpajakan secara jangka panjang terhadap tindakan agresivitas pajak yang dilakukan.

\section{KAJIAN TEORI}

\section{Agency Theory (Teori Agensi)}

Agresivitas pajak yang dilakukan oleh suatu perusahaan merupakan suatu praktik manajemen perpajakan untuk efisiensi pembayaran pajak serta untuk memaksimalkan laba. Tindakan yang dilakukan oleh perusahaan tersebut dapat dijelaskan melalui teori agensi dari Jensen dan Meckling (1976) seperti dikutip oleh Susanto (2018), dimana terdapat kepentingan yang bertolak belakang antara principal dan agent yang dapat mengarah pada asimetri informasi (Susanto et al., 2018). Dalam hal ini pemerintah sebagai principal, berdasarkan ketentuan perundang-undangan melakukan pengawasan serta memiliki kewenangan untuk memperoleh pajak dari penghasilan yang diperoleh oleh perusahaan sebagai agent.

Adanya perbedaan kepentingan inilah yang menyebabkan berbagai praktik di bidang perpajakan yang dilakukan oleh perusahaan yang dapat mengakibatkan penerimaan negara menjadi berkurang ataupun terjadinya kerugian negara (Alkausar et al., 2020). Untuk itulah teori ini dapat dijadikan suatu dasar untuk diwujudkannya suatu tata kelola yang baik bagi suatu perusahaan yang diharapkan mampu meminimalisir adanya praktik yang dapat merugikan kedua belah pihak (Audina, 2020).

\section{Legitimacy Theory (Teori Legitimasi)}

Perusahaan selain menjalankan kegiatan operasionalnya juga memiliki kewajiban untuk dapat memberikan dampak yang bermanfaat bagi komunitas dan lingkungan di sekitarnya. Hal ini diwujudkan perusahaan dalam bentuk aktivitas CSR yang dilakukan secara berkala serta diungkapkan dalam laporan tahunan yang merupakan pertanggungjawaban bagi para stakeholder. Interaksi antara perusahaan dan masyarakat mengacu pada teori legitimasi, dengan melakukan kegiatan CSR yang sesuai dengan nilai dan tanggung jawab sosial maka perusahaan dapat memperoleh legitimasi sosial yang dapat meningkatkan kekuatan perusahaan secara jangka panjang (Indraswari \& Astika, 2015). Dengan kata lain perusahaan juga diharapkan agar dapat mengurangi tindakan agresivitas pajak yang dianggap adanya ketidaksesuaian dengan norma yang dapat merugikan masarakat (Luke et al., 2016).

Pengungkapan CSR memiliki hubungan yang positif dengan agresivitas pajak yang dilakukan oleh perusahaan, perusahaan yang aktif 
melakukan tindakan pajak yang agresif akan cenderung memiliki pengungkapan CSR yang lebih besar untuk dapat mengurangi kerugian yang dapat ditimbulkan dengan adanya praktik tersebut serta untuk mendapatkan kepercayaan dari masyarakat dan komunitas dengan melakukan aktivitas sosial yang mampu memenuhi harapan masyarakat (Lanis \& Richardson, 2013).

\section{Kinerja Perusahaan dan Agresivitas Pajak}

Kinerja suatu perusahaan dapat dilihat baik dari sisi keuangan maupun non keuangan, pengukuran kinerja bertujuan untuk mendapatkan informasi dan gambaran mengenai kondisi suatu perusahaan serta dapat digunakan untuk kepentingan proyeksi kinerja di masa yang akan datang serta untuk dapat menentukan langkah strategis untuk pengembangan bisnis, kinerja dapat diukur melalui analisa laporan keuangan untuk melihat dari sisi keuangan suatu perusahaan (Renfiana \& Dewi, 2020). Kinerja suatu perusahaan dapat diukur menggunakan rasio keuangan ataupun rasio perhitungan lain yang bersifat non keuangan, evaluasi terhadap kinerja perusahaan ditentukan dari kinerja manajemen dimana mereka memiliki tanggung jawab secara eksekutif, jika performa suatu perusahaan tidak memuaskan maka akan berpengaruh terhadap penilaian perusahaan secara keseluruhan (Lin et al., 2019). Ketatnya persaingan di dunia usaha menimbulkan tekanan tersendiri untuk dapat memaksimalkan laba serta berupaya untuk dapat mengurangi resiko beban yang dapat mengurangi pendapatan perusahaan.

Perusahaan sebagai wajib pajak memiliki kewajiban untuk membayarkan sejumlah pajak atas penghasilan kena pajak yang diperoleh dari usaha atau aktivitas operasionalnya. Setiap pembayaran pajak merupakan beban yang harus ditanggung oleh perusahaan yang dapat mengurangi laba bersih yang diperoleh, dengan demikian adanya perbedaan kepentingan antara perusahaan yang berupaya untuk memaksimalkan laba dengan pemerintah yang memaksimalkan penerimaan dari sumber perpajakan hal ini sejalan dengan prinsip dari teori agensi dimana adanya perbedaan kepentingan inilah yang menyebabkan suatu perusahaan melakukan upaya tertentu untuk dapat melakukan tindakan perencanaan pajak yang agresif (Dinar et al., 2020).

Agresivitas pajak merupakan suatu tindakan untuk meminimalisir resiko perpajakan yang dilakukan baik secara legal, ilegal maupun perpaduan dari keduanya (Lanis \& Richardson, 2012). Agresivitas pajak dilakukan dengan cara melakukan rekayasa laba kena pajak melalui perencanan pajak, agresivitas pajak jika dikaji dengan cara yang tepat dan tidak menyimpang dari peraturan yang berlaku akan memberikan manfaat bagi perusahaan (Susanto et al., 2018). Seberapa besar suatu perusahaan melakukuan agresivitas pajak diukur menggunakan Tarif Pajak Efektif (Effective Tax rate/ETR) sebagai proksi tingkat agresivitas pajak (Lanis \& Richardson, 2013; Mohanadas et al., 2019).

$$
\text { Tarif Pajak Efektif }=\frac{\text { Beban Pajak Total }}{\text { Pendapatan Sebelum Pajak }}
$$

\section{Pengungkapan Corporate Social Responsibility (CSR)}

Pengungkapan Corporate Social Responsibility merupakan pelaporan dari wujud tanggung jawab sosial suatu perusahaan atas dampak sosial dan lingkungan dari kegiatan ekonomi perusahaan terhadap komunitas serta masyarakat pada umumnya, pengungkapan CSR didasarkan atas pedoman atau standar yang berlaku untuk dapat menilai seberapa besar aktivitas CSR yang dilakukan oleh suatu perusahaan (Pratiwi, 2018). Pengungkapan CSR dilakukan sebagai jawaban atas masalah yang ditimbulkan yang berkaitan dengan sosial, lingkungan yang juga berdampak terhadap keuangan (Deitiana, 2015). Pengungkapan CSR bersifat sukarela yang dilakukan perusahaan untuk memberikan informasi sebagai wujud akuntabilitas sosial (Lanis \& Richardson, 2013).

Dalam penelitian ini pengukuran pengungkapan CSR mengacu pada indeks atau indikator yang terdapat pada GRI Standard yang dikeluarkan oleh Global Reporting Initiative (GRI) yang merupakan lembaga dunia yang mengusung konsep pelaporan ekonomi, sosial dan lingkungan untuk mendukung sustainability dimana terdapat 89 indikator yang digunakan untuk sektor pertambangan yang terdiri dari 
kategori ekonomi, sosial dan lingkungan (Global Reporting Initiatives, 2018; Majalah CSR, 2017).

\section{Pengaruh Likuiditas terhadap Agresivitas Pajak}

Likuiditas suatu perusahaan menunjukkan bahwa perusahaan memiliki pendanaan yang baik dan lancar terutama dikaitkan dengan kebutuhan dalam penggunaan dana ataupun sebagai penntu dalam perencanaan investasi. Likuiditas merupakan kemampuan perusahaan memenuhi kewajiban jangka pendek (Tracy, 2012). Rasio likuiditas menunjukkan tingkat kemampuan perusahaan dalam melunasi kewajiban jangka pendeknya. Semakin tinggi rasio likuiditas suatu perusahaan maka perusahaan tersebut memiliki kondisi arus kas yang lancar sehingga memiliki kemudahan dalam membayar atau melunasi kewajiban jangka pendeknya. Tingkat likuiditas suatu perusahaan dapat dijadikan sebagai salah satu informasi utama bagi para pengambil keputusan dalam menjalankan strategi bisnisnya (Dharmayanti, 2018).

Rasio likuiditas yang digunakan dalam penelitian ini adalah dengan menggunakan Current Ratio (Rasio Lancar) yaitu rasio yang menunjukkan seberapa besar tingkat aktiva lancar yang dimiliki oleh suatu perusahaan dapat digunakan untuk dapat memenuhi kewajiban atau liabilitas jangka pendeknya. Rasio ini diperoleh dengan membandingkan nilai aktiva lancar yang dimiliki oleh perusahaan dengan nilai kewajiban lancarnya yang dimiliki. Semakin tinggi rasio ini maka kemampuan perusahaan pun semakin tinggi dalam memenuhi kewaiban jangka pendeknya.

$$
\text { Rasio Lancar }=\frac{\text { Aset Lancar }}{\text { Kewajiban Lancar }}
$$

Perusahaan yang memiliki tingkat likuiditas yang rendah akan cenderung menghadapi kesulitan dalam melakukan aktivitas pembayaran kewajibannya, dengan rendahnya tingkat likuiditas perusahaan akan cenderung untuk melakukan penundaan pembayaran agar dapat mempertahankan arus kasnya, situasi ini dapat mendorong suatu perusahaan untuk melakukan tindakan agresivitas pajak (Dinar et al., 2020). Kondisi likuiditas suatu perusahaan akan berpengaruh terhadap kemampuan perusahaan dalam menghasilkan laba yang lebih maksimal, dalam kondisi ini maka perusahaan tidak memiliki kesulitan dalam melakukan aktivitas pembiayaan salah satunya terhadap pembayaran kewajiban perpajakannya, hal ini menunjukkan adanya hubungan yang positif bahwa perusahaan akan mengurangi tindakan agresivitas pajaknya (Dharmayanti, 2018). Berdasarkan penjelasan tersebut maka dapat dirumuskan hipotesis bahwa likuiditas memiliki pengaruh terhadap agresivitas pajak.

$\begin{aligned} & \mathrm{H} 1= \text { Likuiditas berpengaruh terhadap agresivitas } \\ & \text { pajak }\end{aligned}$

\section{Pengaruh Profitabilitas terhadap Agresivitas Pajak}

Seluruh kegiatan operasional yang dilakukan dan dikelola oleh suatu perusahaan memiliki tujuan utama untuk dapat menghasilkan laba bagi perusahaan. Tingkat profitabilitas suatu perusahaan merupakan kemampuan perusahaan sejauh mana dapat menghasilkan laba, tingkat profitabilitas sangat berkaitan dengan kinerja suatu perusahaan, peningkatan profitabilitas suatu perusahaan akan sejalan dengan pertumbuhan perusahaan dan nilai perusahaan tersebut. Profitabilitas yang dicapai oleh suatu perusahaan merupakan evaluasi terhadap kinerja perusahaan serta dapat menujukkan seberapa besar nilai suatu perusahaan dikaitkan dengan nilai saham yang dimiliki (Lim \& Rokhim, 2020). Dikaitkan dengan pembiayaan yang dilakukan perusahaan, perusahaan yang profitabilitasnya tinggi juga akan cenderung untuk menggunakan pendanaan secara internal dibandingkan dengan menggunakan hutang pada pihak ketiga (Chandra et al., 2021).

Dalam penelitian ini rasio yang digunakan untuk mengukur profitabilitas suatu perusahaan dengan menggunakan rasio pengembalian aset atau lebih dikenal dengan istilah Return on Asset (ROA), yaitu rasio yang menunjukkan tingkat kemampuan perusahaan dalam menghasilkan laba (EBIT) untuk setiap nilai aset yang dimilikinya.

$$
\text { Return on Asset }=\frac{\text { Laba Sebelum Pajak }}{\text { Total Aset }}
$$


Semakin besar laba yang dihasilkan oleh suatu perusahaan maka beban pajak yang dibayarkan juga akan semakin besar, hal ini mengindikasikan bahwa profitabilitas perusahaan memiliki pengaruh terhadap manajemen perpajakan yang dilakukan oleh perusahaan (Susanto et al., 2018). Perusahaan yang memiliki tingkat ROA yang tinggi akan memiliki tingkat profitabilitas yang tinggi, dengan tingginya ROA yang dimiliki perusahaan maka perusahaan memiliki peluang yang lebih luas dalam mengelola perencanaan dan penerapan perpajakannya dengan lebih efektif dan efisien sesuai dengan ketentuan perpajakan yang berlaku sehingga beban pajak menjadi lebih rendah namun posisi laba sesuai dengan yang diharapkan, dengan demikian maka terdapat pengaruh terhadap agresivitas pajak yang dilakukan oleh perusahaan (Luke et al., 2016). Berdasarkan penjelasan tersebut maka dapat dirumuskan hipotesis bahwa profitabilitas memiliki pengaruh terhadap agresivitas pajak.

\section{$\mathrm{H} 2=$ Profitabilitas berpengaruh terhadap agresivitas pajak}

\section{Pengaruh Ukuran Perusahaan terhadap Agresivitas Pajak}

Ukuran perusahaan merupakan skala yang digunakan untuk menentukan besar kecilnya suatu perusahaan, salah satunya dinilai dari seberapa besar aset yang dimiliki, berdasarkan hal tersebut ukuran perusahaan dapat dikategorikan menjadi perusahaan besar, perusahaan menengah, dan perusahaan kecil (Sari et al., 2013). Selain itu ukuran perusahaan juga dapat memberikan gambaran kekuatan finansial yang dimiliki dan kemampuan perusahaan dalam menangani resiko yang mungkin dapat timbul dalam aktivitas bisnisnya, perusahaan yang memiliki ukuran yang besar cenderung akan memiliki kontrol yang lebih besar terhadap potensi pasar serta memiliki informasi baik secara keuangan maupun non keuangan yang lebih luas dan mendetail yang dapat digunakan untuk kepentingan para stakeholder terutama untuk dapat meningkatkan kepercayaan dari para investor (Kurnia Saputri \& Giovanni, 2021). Semakin besar ukuran perusahaan akan semakin kompleks aktivitas bisnis yang dilakukannya dan dapat menarik perhatian publik lebih besar dibandingkan perusahaan lainnya (Deitiana, 2015). Selain itu perusahaan besar akan mendapatkan pengawasan yang lebih ketat dari pemerintah salah satunya dalam pemenuhan kewajiban dan kepatuhan pembayaran pajak (Irvan \& Wijaya, 2015). Ukuran perusahaan berkaitan dengan akses yang dimiliki terhadap sumber daya, perusahaan dengan ukuran yang besar akan dengan mudah mendapatakan sumber daya yang kompeten dan ahli serta jajaran manajemen yang berpengalaman dalam melakukan dan mengevaluasi perencanaan pajak (Alkausar et al., 2020). Sehingga ukuran perusahaan akan dapat berpengaruh terhadap seberapa besar tindakan agresivitas pajak yang dilakukan. Berdasarkan penjelasan tersebut maka dapat dirumuskan hipotesis bahwa ukuran perusahaan memiliki pengaruh terhadap agresivitas pajak.

\section{$\mathrm{H} 3$ = Ukuran perusahaan berpengaruh terhadap agresivitas pajak}

Ukuran perusahaan dalam penelitian ini diukur dengan menggunakan proksi total aset yang dimiliki oleh suatu perusahaan yang dihitung menggunakan Logaritma Natural Total Aset.

Ukuran Perusahaan $=L_{n}($ Total Aset $)$

\section{Pengaruh Komisaris Independen terhadap Agresivitas Pajak}

Keberadaan dewan komisaris independen didalam suatu perusahaan tak lepas dari pemenuhan kewajiban suatu perusahaan dalam melaksanakan tata kelola perusahaan yang baik. Adanya dewan komisaris yang menjalankan peran pengawasan dalam suatu perusahaan menjadi penting dalam mempengaruhi kebijakan serta pengambilan keputusan dari pihak manajerial, semakin besar proporsi komisaris independen dalam suatu perusahaan kinerja manajer akan semakin efektif (Irvan \& Wijaya, 2015). Berdasarkan keputusan Bapeppam mengenai persyaratan komisaris independen dalam suatu perusahaan adalah (1) berasal dari luar perusahaan 
dan tidak menjalankan fungsi eksekutif dalam waktu enam bulan terakhir; (2) tidak mempunyai saham langsung maupun tidak langsung pada emiten tersebut; (3) tidak memiliki hubungan afiliasi dengan emiten dan pihak manapun dalam emiten tersebut; (4) tidak memiliki hubungan usaha dengan kegiatan usaha yang dilakukan oleh emiten (Badan Pengawas Pasar Modal dan Lembaga Keuangan, 2012). Peningkatan jumlah komisaris independen sebagai alat pengawasan tersebut akan memberikan kontribusi terhadap berkurangnya tindakan agresivitas pajak (Susanto et al., 2018). Semakin besar proporsi komisaris independen dalam suatu perusahaan akan meningkatkan pengawasan yang lebih ketat kepada pihak manajerial sehingga dapat berpengaruh terhadap agresivitas pajak yang dilakukan oleh manajemen. Dalam menjalankan fungsi eksekutifnya pihak manajerial memiliki kepentingan untuk berupaya memaksimalkan laba sehingga akan berpengaruh terhadap perilaku yang lebih agresif terhadap manajemen pajak yang dilakukan (Irvan \& Wijaya, 2015). Berdasarkan penjelasan tersebut maka dapat dirumuskan hipotesis bahwa komisaris independen memiliki pengaruh terhadap agresivitas pajak.

\section{$\mathrm{H} 4=$ Komisaris independen berpengaruh terhadap agresivitas pajak}

Dalam penelitian ini jumlah komisaris independen diukur dengan seberapa besar proporsi komisaris independen dalam suatu perusahaan yaitu dengan persentase anggota komisaris independen yang berasal dari luar perusahaan dibandingkan dengan seluruh dewan komisaris perusahaan (Sari et al., 2013).

$$
\text { Proporsi Komisaris Independen }=\frac{\text { Jumlah Komisaris Independen }}{\text { Total Dewan Komisaris }}
$$

\section{Pengungkapan Corporate Social Responsibility sebagai Moderasi}

Aktivitas sosial yang dilakukan oleh perusahaan atau lebih dikenal dengan istilah Corporate Social Responsibility tertuang dalam laporan tahunan pengungkapan CSR atau CSR Disclosure, laporan ini memberikan informasi daftar aktivitas sosial yang dilakukan perusahaan dalam satu periode tahun buku perusahaan. Informasi ini terkait dengan keberlangsungan hidup perusahaan, agar investor tetap mempertahankan investasinya karena perusahaan memiliki tingkat sustainability yang diperoleh dari pengungkapan CSR tersebut.

Perusahaan dengan tingkat likuiditas yang tinggi akan lebih banyak melakukan kegiatan sosial yang menunjukkan perusahaan memiliki kinerja yang lebih bagus dan akan menunjukkan perusahaan makin kredibel dan menarik investor untuk berinvestasi (Kamil \& Herusetya, 2012). Hal ini menunjukkan likuiditas berpengaruh terhadap pengungkapan CSR (Putri, 2014). Perusahaan dihadapkan pada persaingan global, stakeholder tidak hanya menuntut perusahaan untuk memperoleh laba yang maksimal tapi juga adanya kepedulian terhadap lingkungan sosial. Aktivitas sosial yang dilakukan dapat memberikan kesan yang baik kepada stakeholder dengan harapan dapat meningkatkan laba perusahaan. Hal ini menunjukkan adanya pengaruh profitabilitas terhadap pengungkapan CSR (Indraswari \& Astika, 2015).

Perusahaan dengan ukuran yang besar, akan sangat diperhatikan oleh stakeholder untuk memenuhi peraturan dan ketentuan yang berlaku. Perusahaan diharapkan dapat menunjukkan akuntabilitas melalui pengungkapan CSR dan mendapatkan legitimasi dari stakeholder yang berdampak pada going concern perusahaan. Dapat dilihat bahwa ukuran perusahaan dapat mempengaruhi pengungkapan CSR (Deitiana, 2015; Indraswari \& Mimba, 2017).

Pengungkapan CSR dipengaruhi adanya komisaris independen yang dapat memberikan pengendalian dan pengawasan terhadap pelaporan CSR. Dapat dilihat adanya pengaruh komisaris independen terhadap pengungkapan CSR (Badjuri, 2011).

Pengungkapan CSR diharapkan dapat dilaporkan secara luas oleh perusahaan sebagai faktor untuk mengurangi agresivitas pajak yang dilakukan perusahaan (Zeng, 2012). Perusahaan yang memiliki aktivitas CSR yang tinggi dilihat sebagai perusahaan yang bertanggungjawab dan memiliki tindakan etis dan moral yang lebih 
tinggi, kecenderungan ini menjadikan perusahan memperoleh reputasi yang baik sehingga dapat menutupi persoalan yang negatif, sehingga bisa dikatakan perusahaan dengan aktivitas CSR yang tinggi berkemungkinan mengadopsi agresivitas pajak yang masif (Lin et al., 2019). Berdasarkan penjelasan tersebut maka dapat dirumuskan hipotesis sebagai berikut :

H5 = Pengungkapan CSR memoderasi pengaruh likuiditas terhadap agresivitas pajak

H6 = Pengungkapan CSR memoderasi pengaruh profitabilitas terhadap agresivitas pajak

$\mathrm{H} 7$ = Pengungkapan CSR memoderasi pengaruh ukuran perusahaan terhadap agresivitas pajak

$\mathrm{H} 8$ = Pengungkapan CSR memoderasi pengaruh proporsi komisaris independen terhadap agresivitas pajak

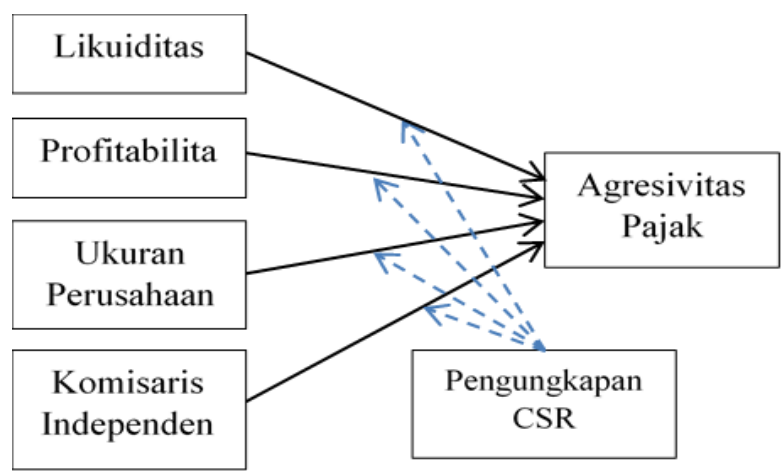

Gambar 1.Model Penelitian

\section{METODOLOGI}

\section{Jenis dan Metode Penelitian}

Penelitian ini dikategorikan sebagai jenis penelitian kuantitatif, data yang digunakan dalam penelitian ini menggunakan data sekunder. Metode penelitian yang digunakan adalah metode deskriptif dan verifikatif, dimana metode penelitian deskriptif merupakan penelitian yang menganalisis data secara sistematik yang didesain untuk menggambarkan dan memahami karakteristik orang, objek, peristiwa atau situasi. Tujuan dari penelitian ini adalah untuk menggambarkan aspek yang relevan dalam suatu fenomena dari berbagai sudut pandang sehingga dapat ditarik suatu kesimpulan untuk memberikan informasi sebagai bahan pertimbangan bagi para pengguna penelitian (Sekaran, 2003). Sedangkan metode verifikatif yaitu metode yang digunakan untuk menguji kebenaran hipotesis, data yang dikumpulkan dianalisa berdasarkan teori-teori yang ada untuk kemudian diuji apakah terdapat pengaruh dari variabel-variabel penelitian sehingga dapat diperoleh kesimpulan dan saran yang dapat bermanfaat.

\section{Populasi dan Sampel}

Populasi yang digunakan adalah seluruh perusahaan pada industri pertambangan yang terdafar pada Bursa Efek Indonesia (BEI) sebanyak 52 perusahaan. Teknik pengambilan sampel yang digunakan dalam penelitian ini adalah non probability sampling dengan metode purposive sampling untuk dapat mengumpulkan data berdasarkan kriteria-kriteria yang ditentukan oleh penulis. Adapun kriteria sampel yang ditentukan adalah sebagai berikut :

1. Perusahaan di industri sektor pertambangan yang terdaftar di Bursa Efek Indonesia pada periode 2018 hingga 2019.

2. Perusahaan di industri pertambangan yang secara konsisten mempublikasikan laporan tahunan maupun laporan keuangan periode 2018-2019 secara berturut-turut baik di situs resmi milik perusahaan dan situs resmi milik Bursa Efek Indonesia.

3. Perusahaan di industri sektor pertambangan yang terdafar di Bursa Efek Indonesia yang tidak membukukan kerugian pada periode 2018 hingga 2019.

4. Memiliki laporan tahunan Pengungkapan CSR yang dipublikasikan pada periode 2018-2019 secara berturut-turut pada situs resmi milik perusahaan.

5. Memiliki dan mempublikasikan data yang relevan dengan variabel yang digunakan dalam penelitian ini yaitu yang berkaitan dengan data likuiditas, profitabilitas, ukuran perusahaan dan komisaris independen.

Berdasarkan kriteria diatas, diperoleh sebanyak 21 perusahaan pada sektor industri pertambangan di BEI pada periode 2018-2019 yang memenuhi kriteria penelitian dengan estimasi sampel penelitian sebagai berikut : 
Tabel 1. Kriteria Sampling

\begin{tabular}{|c|l|c|}
\hline No. & \multicolumn{1}{|c|}{ Kriteria } & $\begin{array}{c}\text { Jumlah } \\
\text { Perusahaan }\end{array}$ \\
\hline 1 & $\begin{array}{l}\text { Perusahaan yang terdaftar pada } \\
\text { sektor industri pertambangan periode } \\
2018-2019 \text { pada BEI }\end{array}$ & 52 \\
2 & $\begin{array}{l}\text { Perusahaan yang terdaftar pada } \\
\text { sektor pertambangan di BEI setelah } \\
\text { periode 2018 }\end{array}$ & $(5)$ \\
\hline 3 & $\begin{array}{l}\text { Perusahaan yang terdaftar pada BEI } \\
\text { yang delisting di tahun 2019 }\end{array}$ & $(2)$ \\
\hline 4 & $\begin{array}{l}\text { Perusahaan yang terdaftar pada } \\
\text { sektor pertambangan di BEI yang } \\
\text { membukukan kerugian pada periode } \\
\text { 2018-2019 }\end{array}$ & $(24)$ \\
\hline 5 & $\begin{array}{l}\text { Perusahaan yang terdaftar pada } \\
\text { sektor pertambangan di BEI yang } \\
\text { tidak mempublikasikan laporan } \\
\text { pengungkapan CSR pada periode } \\
\text { 2018-2019 }\end{array}$ & 0 \\
\hline 6 & $\begin{array}{l}\text { Perusahaan yang memenuhi kriteria } \\
\text { sampel penelitian }\end{array}$ & 21 \\
\hline \multicolumn{3}{|l|}{ Sumber : www.idx.co.id Periode 2018-2019 }
\end{tabular}

\section{Operasionalisasi Variabel}

Penelitian ini melibatkan variabel likuiditas, profitabilitas, ukuran perusahaan dan komisaris independen sebagai variabel eksogen atau variabel independen yang tidak terikat dengan variabel lainnya, variabel agresivitas pajak sebagai variabel endogen atau variabel dependen yang terikat dengan variabel lainnya, serta variabel pengungkapan CSR sebagai variabel moderasi yaitu variabel yang memperkuat atau memperlemah pengaruh antara variabel dependen dan independen. Operasionalisasi variabel yang digunakan dalam penelitian ini adalah sebagai berikut :

Tabel 2. Operasionalisasi Variabel
\begin{tabular}{|l|l|l|}
\hline Variabel & Indikator & Skala \\
\hline Likuiditas & Rasio Lancar & Rasio \\
\hline Profitabilitas & Return on Asset & Rasio \\
\hline Ukuran perusahaan & $\begin{array}{l}\text { Logaritma Natural } \\
\text { Total Aset }\end{array}$ & Rasio \\
\hline Komisaris Independen & $\begin{array}{l}\text { Proporsi Komisaris } \\
\text { Independen }\end{array}$ & Rasio \\
\hline Agresivitas Pajak & Tarif Pajak Efektif & Rasio \\
\hline Pengungkapan CSR & $\begin{array}{l}\text { Indeks Pengungkapan } \\
\text { CSR }\end{array}$ & Rasio \\
\hline
\end{tabular}

\section{Teknik Pengumpulan dan Analisa Data}

Data yang digunakan dalam penelitian ini adalah data sekunder yaitu data yang diperoleh dari sumber yang sudah ada sebelumnya dari sumber terpercaya yang sudah dipublikasikan secara umum. Dalam hal ini data yang dikumpulkan berdasarkan dokumentasi data perusahaan yang terdaftar di Bursa Efek Indonesia dengan cara mengunduh data yang ada pada situs resmi BEI yaitu www.idx.com sedangkan untuk data lainnya yang berkaitan dengan pengungkapan CSR dikumpulkan dengan mengakses situs resmi dari masing-masing perusahaan yang terdaftar di Bursa Efek tersebut. Selain itu juga digunakan studi pustaka sebagai sumber yang relevan dengan penelitian yaitu melalui buku, majalah, artikel dan jurnal penelitian untuk memperoleh landasan teori dan informasi pendukung lainnya.

Data yang telah dikumpulkan kemudian dianalisis menggunakan metode statistik, untuk melihat pengaruh antar variabel dalam penelitian ini digunakan metode Structural Equation Model (SEM) dengan pendekatan Partial Least Square (PLS). Dalam metode statistik PLS-SEM, model evaluasi dilakukan dengan menilai outer model dan inner model. Evaluasi model pengukuran (outer model) dilakukan dengan menilai validitas dan reliabilitas model, untuk outer model dengan indikator refleksif dievaluasi melalui validitas konvergen dan diskriminan dari indikator pembentuk konstruk laten dan composite realibility serta cronbach alpha untuk blok indikatornya. Evaluasi model struktural (inner model) bertujuan untuk memprediksi hubungan antar variabel laten dan untuk menguji hipotesis penelitian. Evaluasinya dilakukan dengan melihat besarnya presentase varian yang dijelaskan dnegan melihat nilai $R$-Square untuk konstruk laten endogen, tes untuk menguji predictive relevance dan average variance extracted untuk jenis prediksi dengan menggunakan prosedur resampling bootstrapping untuk memperoleh stabilitas dari estimasi.

Untuk menilai quality index atau validasi model pengukuran, model struktural dan keseluruhan model menggunakan Goodness of Fit (GoF) indeks yang juga dapat menyediakan pengukuran sederhana untuk keseluruhan dari prediksi model. GoF indeks dihitung dari akar kuadrat nilai average communality index dan average $R$-squares. Setelah diperoleh data pengujian dari evaluasi model pengukuran atau outer model maka uji hipotesis dapat dilakukan (Ghozali, 2013). 
Uji hipotesis dilakukan dengan melihat nilai $T$-statistic (t hitung) dengan nilai signifikansi yang digunakan adalah 5\% atau 0,05 sehingga. Jika dari pengujian nilai t-hitung $>1.96$ maka Ho diterima sedangkan jika nilai t-hitung $<1,96$ maka Ho ditolak. Nilai t-tabel 1,96 menunjukkan nilai $\mathrm{t}$ tabel untuk dof (degree of freedom) dengan nilai tak terhingga.

\section{PEMBAHASAN DAN HASIL PENELITIAN}

Pengujian terhadap konstruk dievaluasi melalui model pengukuran (outer model) yaitu melalui pengujian validitas dan reliabilitas dengan mengkonstruksi variabel ke dalam diagram jalur, pengujian ini dilakukan untuk menguji indikator yang layak untuk dilajutkan dalam penelitian.
Penelitian ini dikonstruksi ke dalam diagram jalur dengan menggunakan software SmartPls 3.0 dengan teknik analisa PLS-SEM.

\section{Hasil Uji Validitas dan Reliabilitas}

Uji validitas melalui dilakukan melalui uji validitas konvergen, dengan program SmartPls 3.0 pengukuran dapat dilihat melalui Loading Factor untuk tiap indikator konstruk. Rule of thumb yang digunakan untuk menilai validitas konvergen yaitu nilai loading factor harus lebih dari 0,7 untuk penelitian yang bersifat confirmatory. Pengukuran validitas konvergen juga diukur dengan menggunakan nilai AVE (average variance extracted) dimana nilai AVE harus lebih besar dari 0,5 (Ghozali, 2015).

Tabel 3. Loading Factor dan Average Variance Extracted

\begin{tabular}{|l|l|l|l|l|}
\hline \multicolumn{2}{|c|}{ Pengaruh } & \multicolumn{1}{c|}{ Hasil Uji } \\
\cline { 2 - 5 } & $\begin{array}{c}\text { Loading } \\
\text { Factor }\end{array}$ & $\begin{array}{c}\text { Kriteria Uji } \\
(>\mathbf{0 , 7})\end{array}$ & \multicolumn{1}{c|}{$\begin{array}{c}\text { AVE } \\
\text { Kriteria Uji } \\
(>\mathbf{0 , 5})\end{array}$} \\
\hline Likuiditas --> RL & 1.000 & Valid & 1.000 & Valid \\
\hline Profitabilitas --> ROA & 1.000 & Valid & 1.000 & Valid \\
\hline Ukuran Perusahaan --> TA & 1.000 & Valid & 1.000 & Valid \\
\hline Komisaris Independen --> KIP & 1.000 & Valid & 1.000 & Valid \\
\hline Agresivitas Pajak --> ETR & 1.000 & Valid & 1.000 & Valid \\
\hline Pengungkapan CSR --> CSRI & 1.000 & Valid & 1.000 & Valid \\
\hline Likuiditas*Pengungkapan CSR --> Agresivitas Pajak & 0.766 & Valid & 1.000 & Valid \\
\hline Profitabilitas*Pengungkapan CSR --> Agresivitas Pajak & 0.885 & Valid & 1.000 & Valid \\
\hline Ukuran Perusahaan*Pengungkapan CSR --> Agresivitas Pajak & 1.199 & Valid & 1.000 & Valid \\
\hline Komisaris Independen*Pengungkapan CSR --> Agresivitas Pajak & 0.744 & Valid & 1.000 & Valid \\
\hline
\end{tabular}

Nilai loading factor yang ditunjukkan pada tabel diatas menujukkan bahwa indikator yang digunakan memiliki kontribusi terhadap definisi variabel latennya, semakin tinggi nilai loading factor tersebut maka hubungannya semakin kuat antar indikator dan variabelnya yang ditunjukkan dari nilai yang melebihi 0,7 . Nilai AVE yang ditunjukkan pada tabel diatas melebihi nilai 0,5 , dengan demikian dimensi dan variabel dinyatakan valid dan dan terbebas dari kesalahan pengukuran (Joseph F. Hair et al., 2013). Dari tabel diatas menunjukkan bahwa seluruh indikator reflektif serta variabel latennya dikatakan layak untuk digunakan dalam outer model.

Uji Validitas dilakukan juga dengan menggunakan pengukuran validitas diskriminan, pengukuran ini berkaitan dengan suatu prinsip yang menyatakan bahwa indikator terhadap konstruk yang berbeda dalam suatu model penelitian seharusnya tidak berkorelasi tinggi, pengukuran validitas diskriminan diukur dengan melihat nilai dari cross loading factors. Cross loading factors suatu indikator terhadap variabel laten representatifnya harus melebihi 0,7 (Joe F. Hair et al., 2014). 
Tabel 4. Cross Loading Factor

\begin{tabular}{|l|l|l|l|l|l|l|}
\hline Keterangan & Likuiditas & Profitabilitas & $\begin{array}{l}\text { Ukuran } \\
\text { Perusahaan }\end{array}$ & $\begin{array}{l}\text { Komisaris } \\
\text { Independen }\end{array}$ & $\begin{array}{l}\text { Agresivitas } \\
\text { Pajak }\end{array}$ & $\begin{array}{l}\text { Pengungkapan } \\
\text { CSR }\end{array}$ \\
\hline RL & 1.000 & -0.010 & -0.109 & -0.168 & 0.271 & -0.011 \\
\hline ROA & -0.010 & 1.000 & -0.135 & -0.199 & 0.450 & -0.083 \\
\hline TA & -0.109 & -0.135 & 1.000 & 0.240 & -0.253 & 0.474 \\
\hline KIP & -0.168 & -0.199 & 0.240 & 1.000 & -0.157 & -0.079 \\
\hline ETR & 0.271 & 0.450 & -0.253 & -0.157 & 1.000 & -0.039 \\
\hline CSRI & -0.011 & -0.083 & 0.474 & -0.079 & -0.039 & 1.000 \\
\hline
\end{tabular}

Dari tabel diatas nilai cross loading factor untuk semua indikator diatas 0,7 , perhitungan tersebut menyatakan bahwa tidak terdapat nilai korelasi antar indikator terhadap variabel laten lain dengan nilai korelasi yang melebihi variabel representatifnya.

Pengujian reliabilitas dilakukan untuk membuktikan akurasi, konsistensi dan ketepatan instrumen dalam mengukur konstruk dilakukan dengan dua cara yaitu composite reliability dan cronbach alpha (Ghozali, 2013). Cronbach alpha merupakan sebuah ukuran keandalan yang meimiliki nilai berkisar nol sampai dengan satu. Baik composite reliability maupun cronbach alpha mendukung konsistensi internal, dimana nilai kedua pengujian tersebut harus diatas 0,7 untuk dinyatakan reliabel (Joseph F. Hair et al., 2013). Dalam penelitian ini indikator yang digunakan untuk masing-masing konstruk terdiri atas satu indikator sehingga dari hasil pengolahan data nilai Cronbach Alpha dan Composite reliability untuk masing-masing konstruk bernilai 1, hal ini menunjukkan bahwa model memiliki reliabilitas yang tinggi dan seluruh indikator reflektifnya serta variabel latennya dikatakan reliabel untuk digunakan dalam outer model.

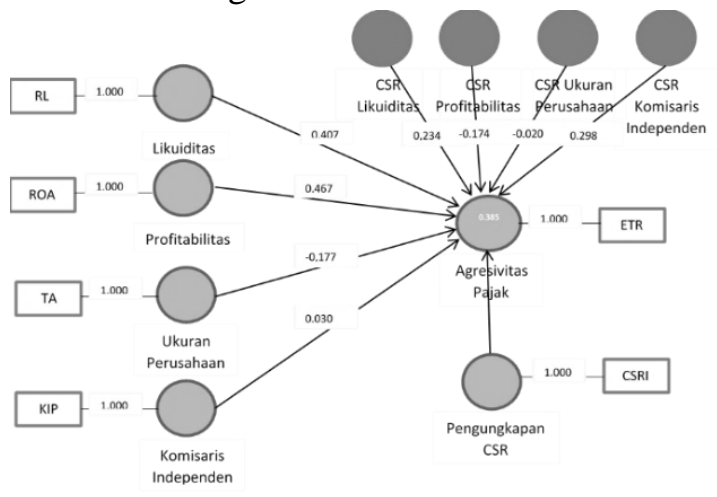

Gambar 2. Diagram Jalur Model Pengukuran

\section{Evaluasi Inner Model}

Dalam menilai struktural menggunakan PLS, kekuatan predikasi inner model dapat dilihat dari nilai $R$-Square untuk setiap variabel laten endogen. Perubahan nilai $R$-Square dapat digunakan untuk menjelaskan pengaruh variabel laten eksogen tertentu terhadap variabel laten endogen apakah mempunyai pengaruh yang substantif. Hasil dari PLS R-Square mempresentasi jumlah varian yang dari konstruk yang dijelaskan oleh model. Nilai $R$-Square ditunjukkan pada tabel dibawah ini :

Tabel 5. Nilai $R$-Square

\begin{tabular}{|l|l|l|}
\hline & R Square & Keterangan \\
\hline Agresivitas Pajak & 0.385 & Moderat \\
\hline
\end{tabular}

Hasil yang diperoleh menunjukkan nilai $R$-Square dalam persentase sebesar $38,5 \%$ dan termasuk dalam kategori moderat, nilai tersebut menunjukkan bahwa variabel agresivitas pajak hanya sebesar 38,5\% yang dapat dijelaskan melalui variabel likuiditas, profitabilitas, ukuran perusahaan dan komisaris independen serta pengungkapan CSR sedangkan selebihnya sebesar 61,5\% lebih banyak dijelaskan oleh faktor lainnya. Pengujian quality of index diukur melalui GoF (Goodness of Fit), indeks ini digunakan untuk mengevaluasi model pengukuran dan model struktural. Nilai GoF dikatakan kecil bila berada diantara $0,1-0,25$, sedang bila berada diantara $0,25-0,36$, serta besar bila berada diatas 0,36 . GoF indeks dihitung dari akar kuadrat nilai average communality index dikalikan dengan average $R$ Square, berdasarkan perhitungan tersebut diperoleh nilai GoF sebesar 0,61 , nilai ini termasuk dalam kategori besar. Nilai GoF mencerminkan bahwa model keseluruhan dan 
indikator pada penelitian ini memiliki kesesuaian yang besar yaitu sebesar $61 \%$.

\section{Analisa Uji Hipotesis}

Untuk menguji hipotesis yang diajukan

untuk melihat pengaruh signifikan terhadap variabel maka dapat dilihat dari besarnya nilai tstatistik atau t-hitungnya. Hasil pengujian dapat dilihat pada tabel dibawah ini :

Tabel 6. Hasil Uji Hipotesis

\begin{tabular}{|l|l|l|l|l|l|l|}
\hline \multicolumn{1}{|c|}{ Keterangan } & $\begin{array}{l}\text { Sampel Asli } \\
(\mathbf{O})\end{array}$ & $\begin{array}{l}\text { Rata-rata } \\
\text { Sampel (M) }\end{array}$ & $\boldsymbol{\alpha}$ & T-hitung & T-table & P Values \\
\hline Likuiditas -> Agresivitas Pajak & 0.407 & 0.385 & 0,05 & 1.744 & 1,96 & 0.082 \\
\hline Profitabilitas -> Agresivitas Pajak & 0.467 & 0.484 & 0,05 & 3.032 & 1,96 & 0.003 \\
\hline Ukuran perusahaan -> Agresivitas Pajak & -0.177 & -0.174 & 0,05 & 0.833 & 1,96 & 0.405 \\
\hline Komisaris independen -> Agresivitas Pajak & 0.030 & 0.017 & 0,05 & 0.156 & 1,96 & 0.876 \\
\hline Pengungkapan CSR -> Agresivitas Pajak & 0.155 & 0.154 & 0,05 & 0.780 & 1,96 & 0.436 \\
\hline CSR memoderasi Likuiditas -> Agresivitas Pajak & 0.234 & 0.188 & 0,05 & 0.741 & 1,96 & 0.459 \\
\hline $\begin{array}{l}\text { CSR memoderasi Profitabilitas -> Agresivitas } \\
\text { Pajak }\end{array}$ & -0.174 & -0.214 & 0,05 & 0.723 & 1,96 & 0.470 \\
\hline $\begin{array}{l}\text { CSR memoderasi Ukuran perusahaan thdp -> } \\
\text { Agresivitas Pajak }\end{array}$ & -0.020 & -0.031 & 0,05 & 0.141 & 1,96 & 0.888 \\
\hline $\begin{array}{l}\text { CSR memoderasi Komisaris independen thdp -> } \\
\text { Agresivitas Pajak }\end{array}$ & 0.298 & 0.286 & 0,05 & 0.968 & 1,96 & 0.334 \\
\hline
\end{tabular}

Berdasarkan hasil pengujian diatas, analisa secara parsial pengaruh likuiditas terhadap agresivitas pajak menunjukkan nilai pada t-hitung $<$-table $(1,744<1,96)$, dari hasil perhitungan ini menunjukkan bahwa likuiditas tidak berpengaruh signifikan terhadap agresivitas pajak, dari nilai original sampel yang positif menunjukkan bahwa likuiditas memiliki hubungan yang positif terhadap agresivitas pajak, semakin besar kemampuan perusahaan dalam membayar kewajiban jangka pendeknya dimana perusahaan dalam kondisi memiliki arus kas yang lancar maka perusahaan memiliki posisi untuk dapat meningkatkan agresivitas pajak dalam manajemen perpajakannya, demikian sebaliknya. Namun oleh karena hasil pengujian menunjukkan pengaruh yang tidak signifikan dapat dikatakan bahwa peningkatan maupun penurunan likuiditas suatu perusahaan tidak mempengaruhi peningkatan maupun penurunan agresivitas pajak perusahaan sehingga dalam hal ini hipotesis pertama ditolak.

Kemampuan perusahaan untuk dapat memperoleh laba ditunjukkan dengan rasio profitabilitas dalam suatu perusahaan, dari hasil pengujian secara parsial profitabilitas terhadap agresivitas pajak menunjukkan nilai t-hitung $>t$ table $(3,032>1,96)$, dari hasil perhitungan ini menunjukkan bahwa profitabilitas berpengaruh positif dan signifikan terhadap agresivitas pajak, semakin meningkat laba yang yang diperoleh oleh perusahaan maka semakin meningkat pula beban pajak yang dibayarkan oleh perusahaan, hal ini menjadi salah satu indikasi semakin meningkatnya agresivitas pajak yang dilakukan perusahaan, dengan demikian dari hasil pengujian tersebut hipotesis kedua diterima. Perusahaan yang memiliki performa keuangan yang baik akan memiliki kemudahan dan peluang yang lebih luas dalam mengelola perpajakannya, hasil pengujian ini didukung oleh teori agensi dimana manajemen akan tetap berupaya untuk memaksimalkan laba perusahaan.

Hasil pengujian secara parsial variabel ukuran perusahaan terhadap agresivitas pajak menunjukkan nilai t-hitung $<$-table $(0,833<1,96)$, hal ini dapat diartikan bahwa ukuran perusahaan tidak memiliki pengaruh yang signifikan terhadap agresivitas pajak. Hubungan antara ukuran perusahaan dan agresivitas pajak juga menujukkan hasil yang negatif dimana hal ini dapat diartikan bahwa semakin besar ukuran suatu perusahaan yang dinilai dari besarnya total aset perusahaan tidak serta merta meningkatkan tindakan agresivitas pajak yang dilakukan atau, 
hal ini menunjukkan bahwa perusahaan kecil atau menengah juga berpotensi untuk melakukan tindakan agresivitas pajak, tidak hanya dilakukan oleh perusahaan besar, dengan demikian maka hipotesis ketiga ditolak.

Berdasarkan hasil pengujian $t$ pada variabel komisaris independen yang diukur menggunakan proporsi komisaris independen menunjukkan bahwa t-hitung $<t$-table $(0,156<1,96)$ dapat ditarik kesimpulan bahwa proporsi komisaris independen tidak berpengaruh signifikan terhadap agresivitas pajak, hasil ini megindikasikan bahwa semakin banyak jumlah komisaris independen tidak menurunkan tindakan agresivitas pajak yang dilakukan oleh perusahaan, hal ini dapat diindikasikan bahwa peran pengawasan untuk mempengaruhi keputusan manajemen dalam melakukan tindakan agresivitas pajak belum efektif, dengan demikian hipotesis keempat ditolak.

Pengujian secara parsial terhadap pengungkapan CSR terhadap agresivitas pajak menunjukkan hasil t-hitung $<t$-table $(0,155<1,96)$, hasil perhitungan ini menunjukkan bahwa pengungkapan CSR tidak berpengaruh signifikan terhadap agresivitas pajak, namun menujukkan hubungan yang positif antara pengungkapan CSR dengan agresivitas pajak dalam hal ini semakin banyak pengungkapan CSR oleh perusahaan maka perusahaan akan semakin banyak melakukan tindakan agresivitas pajak, namun demikian dari hasil pengujian yang dilakukan hal ini tidaklah berpengaruh signifikan, perusahaan yang melakukan pengungkapan CSR yang lebih sedikit pun dapat melakukan tindakan agresivitas pajak.

Hasil pengujian pengungkapan CSR sebagai pemoderasi menunjukkan bahwa pengungkapan CSR tidak memoderasi hubungan antara variabel likuiditas, profitabilitas, ukuran perusahaan dan komisaris independen terhadap agresivitas pajak, hal ini ditunjukkan dari besarnya t-hitung masing-masing variabel lebih kecil dibandingkan nilai $t$-table masing-masing variabel. Dengan demikian besarnya pengungkapan CSR dan aktivitas CSR yang dilakukan oleh perusahaan tidak berpengaruh untuk memperkuat atau memperlemah hubungan pengaruh antara variabel likuiditas, profitabilitas, ukuran perusahaan, komisaris independen terhadap tindakan agresivitas pajak yang dilakukan oleh perusahaan. Hal tersebut dapat menunjukkan bahwa pelaporan CSR tidak mengurangi agresivitas pajak yang dilakukan perusahaan sehingga perusahaan akan tetap agresif dalam menangani pajak untuk meminimalkan beban pajak sehingga laba yang dihasilkan dapat maksimal.

\section{KESIMPULAN}

Penelitian ini menguji pengaruh dari variabel likuiditas, profitabilitas, ukuran perusahaan, komisaris independen terhadap agresivitas pajak pada perusahaan pertambangan di Indonesia yang terdaftar pada Bursa Efek Indonesia. Selain itu pengujian juga dilakukan bagaimana pengungkapan CSR berdasarkan aktivitas yang mencakup bidang ekonomi, lingkungan dan sosial oleh suatu perusahaan dapat memoderasi hubungan variabel likuiditas, profitabilitas, ukuran perusahaan dan komisaris independen terhadap agresivitas pajak yang dilakukan oleh perusahaan.

$$
\text { Pengujian dilakukan dengan }
$$

menggunakan data sekunder yang dianalisa melalui metode PLS-SEM, dari pengujian tersebut diperoleh hasil bahwa secara parsial hanya variabel profitabilitas berpengaruh signifikan terhadap agresivitas pajak sedangkan pengungkapan CSR sebagai pemoderasi tidak memiliki pengaruh untuk memperkuat hubungan antara variabel likuiditas, profitabilitas, ukuran perusahaan dan komisaris independen terhadap agresivitas pajak. Penelitian ini berfokus pada perusahaan pertambangan yang merupakan salah satu industri yang berperan aktif terhadap aktivitas CSR hal ini mengindikasikan bahwa pengungkapan CSR yang dilakukan telah memadai, namun pengungkapan CSR yang dilakukan perusahaan tidak berpengaruh untuk memperkuat ataupun mengurangi tindakan agresivitas pajak yang dilakukan oleh perusahaan, dengan demikian perusahaan yang memiliki tingkat pengungkapan CSR yang rendah pun memiliki kecenderungan untuk dapat melakukan tindakan agresivitas pajak. 
Perusahaan yang memiliki performa keuangan yang baik dalam hal perolehan laba serta meniliki tingkat profitabilitas yang tinggi akan lebih mendapatkan keuntungan dan peluang dalam melakukan agresivitas pajak untuk dapat memaksimalkan laba perusahaan, hal ini sejalan dengan penelitian sebelumnya yang menyatakan bahwa perusahaan akan memperoleh posisi yang lebih mudah dalam melakukan manajemen perpajakan untuk mengefisiensikan beban pajak yang ditanggung oleh perusahaan (Luke et al., 2016). Dengan demikian pengawasan terhadap perusahaan dalam mematuhi peraturan perpajakan yang berlaku perlu lebih ditingkatkan tidak terbatas hanya pada perusahaan dengan tingkat profitabilitas yang rendah.

Pengungkapan CSR yang dilakukan pun tidak dapat mengurangi agresivitas pajak, sehingga perusahaan yang semakin agresif dalam perencanaan perpajakan harus dapat mematuhi peraturan perundang-undangan perpajakan yang berlaku guna menghindari tindakan ilegal yang pada akhirnya dapat merugikan dan menjatuhkan kredibilitas perusahaan. Pencegahan dapat dilakukan dengan meminta perusahaan multinasional untuk secara terbuka mengungkapkan kegiatan bisnis termasuk pembayaran pajak berdasarkan laporan per negara, sebagai cara untuk mendeteksi dan mencegah praktik penghindaran pajak yang tidak tepat (Kar \& Spanjers, 2014). Perusahaan diharapkan untuk dapat mengontrol dan mengelola pelaksanaan kewajiban perpajakannya dengan lebih baik untuk menghindari resiko beban dan utang pajak yang tak terduga di masa mendatang serta meningkatkan transparansi untuk dapat mengurangi resiko ketidakpatuhan dalam menjalankan transaksi perpajakannya.

\section{DAFTAR PUSTAKA}

Agincourt Resources. (2019). Penerapan Corporate Social Responsibility. https://www.agincourtresources.com/readagincourt/penerapan-corporate-socialresponsibility-untuk-industri-tambang/

Alkausar, B., Lasmana, M. S., \& Soemarsomo, P. N. (2020). Agresivitas Pajak: Sebuah Meta
Analisis dalam Persepektif Agency Theory. The International Journal of Applied Business Tijab, 4(1), 52-62.

Audina, N. M. (2020). The Effect of Corporate Governance on Earnings Management with Capital Structure as Intervening Variable. Journal of Business Management Review, 1(2), 090-106. https://doi.org/10.47153/jbmr12.162020

Badan Pengawas Pasar Modal dan Lembaga Keuangan. (2012). Pembentukan dan Pedoman Pelaksanaan Kerja Komite Audit. 2004.

Badjuri, A. (2011). Faktor-Faktor fundamental, mekanisme coorporate governance, pengungkapan coorporate social responsibility (CSR) perusahaan manufaktur dan sumber daya alam di Indonesia. Dinamika Keuangan Dan Perbankan, 3(1), 38-54.

Chandra, T., Junaedi, A. T., Wijaya, E., \& Ng, M. (2021). The impact of co-structure of capital, profitability and corporate growth opportunities on stock exchange in Indonesia. Journal of Economic and Administrative Sciences, ahead-of-p(aheadof-print). https://doi.org/10.1108/jeas-082019-0081

Deitiana, T. (2015). The Determinant of CSR Disclosure of Mining Industry Listed in Indonesia Stock Exchange. Asian Business Review, 5(3), 141. https://doi.org/10.18034/abr.v5i3.664

Dharmayanti, N. (2018). Pengaruh Likuiditas, Leverage dan Profitabilitas, Terhadap Agresivitas Pajak. Jurusan Akuntansi Fakultas Ekonomi Dan Bisnis Universitas Islam Syekh Yusuf Tangerang, 1-14.

Dinar, M., Yuesti, A., \& Dewi, N. P. S. (2020). Pengaruh Profitabilitas, Likuiditas Dan Leverage Terhadap Agresivitas Pajak Pada Perusahaan Manufaktur Yang Terdaftar Di Bei. Jurnal Kharisma, 2(1), 66-73.

Dunia Tambang. (2020). Ragam Bentuk CSR yang Dapat Dilakukan Perusahaan Pertambangan. 12-11-2020. https://duniatambang.co.id/Berita/read/1352/ Ragam-Bentuk-CSR-yang-Dapat- 
Dilakukan-Perusahaan-Pertambangan

Elkington, J. (2004). Enter the Triple Bottom

Line.

https://www.johnelkington.com/archive/TB

L-elkington-chapter.pdf

Ghozali, I. (2013). Aplikasi Analisis Mulvariate dengan program IBM SPSS. Edisi Ke, 7.

Ghozali, I. (2015). Partial Least Square. Konsep, Teknik dan Aplikasi Menggunakan program SmartPls 3.0 (2nd ed.). Badan Penerbit Universitas Diponegoro.

Global Reporting Initiatives. (2018). Disclosures Mining and Metals.

Hair, Joe F., Sarstedt, M., Hopkins, L., \& Kuppelwieser, V. G. (2014). Partial least squares structural equation modeling (PLSSEM): An emerging tool in business research. European Business Review, 26(2), 106-121. https://doi.org/10.1108/EBR-102013-0128

Hair, Joseph F., Ringle, C. M., \& Sarstedt, M. (2013). Partial Least Squares Structural Equation Modeling: Rigorous Applications, Better Results and Higher Acceptance. Long Range Planning, 46(1-2), 1-12. https://doi.org/10.1016/j.lrp.2013.01.001

Indraswari, \& Astika, I. B. P. (2015). Pengaruh Profitabilitas, Ukuran Perusahaan, dan Kepemilikan Saham Publik terhadap Pengungkapan. E-Jurnal Akuntansi Universitas Udayana, 1, 289-302.

Indraswari, I. G. A. L., \& Mimba, N. P. S. H. (2017). Pengaruh Profitabilitas, Pertumbuhan Perusahaan, Kapitalisasi Pasar Dan Kepemilikan Saham Publik Pada Tingkat Pengungkapan Csr. E-Jurnal Akuntansi Universitas Udayana, 20(2), 1219-1248. https://doi.org/10.24843/EJA.2017.v20.i02.p 13

Irvan, T., \& Wijaya, H. (2015). Pengaruh Likuiditas, Leverage, Manajemen Laba, Komisaris Independen dan Ukuran Perusahaan terhadap Agresivitas Pajak. XIX(03), 380-397.

Kamil, A., \& Herusetya, A. (2012). Pengaruh karakteristik perusahaan terhadap luas pengungkapan kegiatan corporate social responsibility. Media Riset Akuntansi, 2(1).

Kar, D., \& Spanjers, J. (2014). Illicit Financial Flows from Developing Countries: 2003 2012. Global Financial Integrity.

Kemenkumham. (2012). Peraturan Pemerintah No. 47 Tahun 2012 tentang Tanggung Jawab Sosial Dan Lingkungan Perseroan Terbatas.

Kurnia Saputri, C., \& Giovanni, A. (2021). The The Effect Of Profitability, Size And Liquidity on Firm Value in Consumer Goods Industry Listed on The Indonesia Stock Exchange (IDX). Journal of Business Management Review, 2(2), 092-106. https://doi.org/10.47153/jbmr22.902021

Lanis, R., \& Richardson, G. (2012). Corporate social responsibility and tax aggressiveness: An empirical analysis. Journal of Accounting and Public Policy, 31(1), 86108.

https://doi.org/10.1016/j.jaccpubpol.2011.10 .006

Lanis, R., \& Richardson, G. (2013). Corporate social responsibility and tax aggressiveness: A test of legitimacy theory. Accounting, Auditing and Accountability Journal, 26(1), 75-100.

https://doi.org/10.1108/09513571311285621

Lim, H., \& Rokhim, R. (2020). Factors affecting profitability of pharmaceutical company: an Indonesian evidence. Journal of Economic Studies, 2010. https://doi.org/10.1108/JES01-2020-0021

Lin, X., Liu, M., So, S., \& Yuen, D. (2019). Corporate social responsibility, firm performance and tax risk. Managerial Auditing Journal, 34(9), 1101-1130. https://doi.org/10.1108/MAJ-04-2018-1868

Luke, dan, \& Zulaikha. (2016). Analisis Faktor yang Mempengaruhi Agresivitas Pajak. Jurnal Akuntansi \& Auditing, 13(1), 80-96.

Majalah CSR. (2017). Peluncuran GRI Standards 2018: Membaca Arah Akuntabilitas Masa Depan. $12 \quad$ June 2017. https://majalahcsr.id/peluncuran-gristandards-2018-membaca-arahakuntabilitas-masa-depan/2/

Mohanadas, N. D., Abdullah Salim, A. S., \& 
Pheng, L. K. (2019). CSR and tax aggressiveness of Malaysian listed companies: evidence from an emerging economy. Social Responsibility Journal, 16(5), 597-612. https://doi.org/10.1108/SRJ01-2019-0021

Pratiwi, A. P. (2018). Pengaruh Kepemilikan Institusional Dan Kinerja Keuangan Terhadap Penghindaran Pajak Dengan Corporate Sosial Responsibility Sebagai Pemediasi Kepemilikan Institusional Dan Kinerja Keuangan Terhadap Penghindaran Pajak Dengan Corporate Sosial Responsibility. Jurnal Ilmu Manajemen \& Bisnis, 9(2), 58-66.

Purwanto, A., Yusralaini, Y., \& Susilatri, S. (2016). Pengaruh likuiditas, leverage, manajemen laba, dan kopensasi rugi fiskal terhadap agresivitas pajak perusahaan pada perusahaan pertanian dan pertambangan yang terdaftar di bursa efek indonesia periode 2011-2013. Riau University.

Putri, R. A. (2014). Pengaruh Profitabilitas, Likuiditas, dan Leverage Terhadap Pengungkapan CSR. Business Accounting Review, 2(1), 61-70.

Renfiana, L., \& Dewi, S. C. (2020). The Effect of Company's Performance on Tax Avoidance. Journal of Business Management Review, 1(2), 107-120. https://doi.org/10.47153/jbmr12.312020

Saputra, W., \& Abdullah, M. (2015). Aliran uang haram dan kejahatan perpajakan di sector pertambangan. Publish What You Pay.

Sari, A. R., Sutrisno, \& Sukoharsono, E. G. (2013). Pengaruh Kepemilikan Institusional, Komposisi Dewan Komisaris, Kinerja Perusahaan terhadap Luas Pengungkapan Corporate Social Responsibility di dalam Sustainability Report pada Perusahaan Manufaktur yang Terdaftar di BEI. Jurnal Aplikasi Manajemen, 11(3), 481-491.

Sugianto, D. (2019). Dituduh Gelapkan Pajak, Adaro Beberkan Setor Rp $10 \mathrm{~T}$ ke Negara. 04 Jul 2019. https://finance.detik.com/bursadan-valas/d-4611541/dituduh-gelapkanpajak-adaro-beberkan-setor-rp-10-t-kenegara
Susanto, L., Yanti, Y., \& Viriany, V. (2018). Faktor-faktor yang mempengaruhi agresivitas pajak. Jurnal Ekonomi, 23(1), 10-19. https://doi.org/10.24912/je.v23i1.330

Tracy, A. (2012). Ratio analysis fundamentals: how 17 financial ratios can allow you to analyse any business on the planet. RatioAnalysis. net.

Undang-undang RI No. 4 tahun 2009. (2009). Undang-Undang Tentang Pertambangan Mineral Dan Batubara. In Pertambangan Mineral Dan Batubara.

Undang-undang RI No.40 Tahun 2007. (2007). Undang-Undang Republik Perseroan Terbatas. www.hukumonline.com

Undang-undang RI No 36 Tahun 2008. (2008). Undang-undang RI No.36 Tahun 2008 tentang perubahan Keempat atas UU No.7 Tahun 1983 tentang Pajak Penghasilan. 121.

Zeng, T. (2012). Corporate Social Responsibility and Tax Aggressiveness. SSRN Electronic Journal. https://doi.org/10.2139/ssrn.2178471 